\title{
MOVIMENTOS SOCIAIS FRENTE ÀS GRANDES MINERADORAS NO BRASIL
}

\author{
Antonio José de Mattos Neto \\ Doutor em Direito pela Universidade de São Paulo. Professor no Programa de Pós-Graduação \\ em Direito do Instituto de Ciências Jurídicas da Universidade Federal do Pará, do qual já \\ foi Diretor-Geral. Professor no Programa de Pós-Graduação em Direito da Universidade da \\ Amazônia. Membro da União Mundial de Agraristas Universitários. Membro Fundador da \\ Academia Brasileira de Letras Agrárias. Membro Fundador e Vice-Presidente da Academia \\ Paraense de Letras Jurídicas. Advogado. Membro do Instituto Histórico e Geográfico do Pará. \\ Email: antoniojosedemattosneto@gmail.com \\ Romário Edson da Silva Rebelo \\ Mestrando em Direito, na área de concentração "Direitos Humanos" e na linha de pesquisa \\ "Direitos Humanos e Inclusão Social", pelo Programa de Pós-Graduação em Direito \\ do Instituto de Ciências Jurídicas da Universidade Federal do Pará. Pós-Graduando em \\ Amazônia, História, Espaço e Cultura pelo Departamento de História das Faculdades \\ Integradas Brasil Amazônia. Advogado. \\ Email: romariorebelo@live.com
}

\section{RESUMO}

A partir de uma pesquisa de dados primários, este trabalho se propôs a levantar e a analisar algumas estratégias e constraestratégias de movimentos sociais que fazem frente à atividade de extração de minérios no Brasil, com o objetivo de verificar como se formam e se desenrolam os conflitos decorrentes dos impactos socioambientais e violações de direitos humanos causados pelas grandes mineradoras no país. Para tanto, primeiro se situou o problema a partir da compreensão do modo como se põe em prática essa atividade, para que, em seguida, a atenção se dirigisse ao que está em disputa entre os diferentes agentes que compõem esse campo de tensão, para que, ao final, fosse possível compreender algumas estratégias e contraestratégias desses movimentos sociais, principalmente aquelas relacionadas ao novo marco regulatório da mineração, então elaborado pelo Governo Dilma, e às medidas provisórias do setor recentemente editadas pelo Governo Temer. Com isso, chegou-se à conclusão de que as frentes de resistência, mobilização popular e articulação política se prestam a desconstruir as "verdades" difundidas pelas grandes mineradoras, mostrando o quanto elas violam direitos humanos, principalmente daqueles que se encontram numa condição histórica e econômica de vulnerabilização. 
Palavras-chave:movimentos sociais; estratégias e contraestratégias; grandes mineradoras; impactos socioambientais; violações de direitos humanos.

\title{
SOCIAL MOVEMENTS AGAINST LARGE MINING COMPANIES IN BRAZIL
}

\begin{abstract}
Based on a survey of primary data, this paper aims to analyze and analyze some strategies and counter strategies of social movements that deal with the extraction of ores in Brazil, in order to verify the formation and development of conflicts arising from social and environmental impactsand human rights violations caused by large mining companies in the country. To do so, the problem was first situated through an understanding of the way in which this activity is carried out, so that the attention is then directed to what is in dispute between the different agents that compose this field of tension, so that , in the end, it was possible to understand some strategies and counter strategies of these social movements, especially those related to the new mining regulatory framework, then elaborated by the Dilma Government, and to the provisional measures of the sector recently edited by the Temer Government. This led to the conclusion that the fronts of resistance, popular mobilization and political articulation lend themselves to deconstructing the "truths" disseminated by the big mining companies, showing how much they violate human rights, especially those who are in a historical and of vulnerability.
\end{abstract}

Keywords: social movements; strategies and counterstrategies; large mining companies; social and environmental impacts; violations of human rights. 


\title{
INTRODUÇÃO
}

Mesmo estando entre as maiores financiadoras da mídia nacional, grandes mineradoras não vêm conseguindo abafar muitos dos conflitos decorrentes da atividade de extração de minérios no Brasil e, até mesmo, em outros países onde já se instalou algum empreendimento do setor. Supõese que isso se deva aos grandes impactos socioambientais intrínsecos à maneira de pôr em prática essa atividade -como dão a entender casos como o da Samarco S/A, cuja barragem de rejeitos de minérios rompeu no final de 2015 em Mariana, Minas Gerais, afetando mais de 30 cidades $^{1}{ }^{-}$, ou às estratégias e contraestratégias assumidas por muitos movimentos sociais para dar visibilidade a esses impactos e divulgar violações a direitos humanos por parte das grandes mineradoras, a exemplo do Public Eye Awards, conhecido popularmente como o "Nobel da Vergonha", dado à Vale S/A em $2012^{2}$.

Entende-se por estratégia toda ação de resistência, isolada ou articulada, de iniciativa dos movimentos sociais,tipicamente insurgentes aos impactos socioambientais, sejam eles reais ou potenciais, decorrentes da atividade de extração de minérios. E, por contraestratégias, as ações tomadas por esses mesmos movimentos sociais em resposta às investidas

\begin{abstract}
1 Em 13 de fevereiro de 2016, a Samarco S/A, uma subsidiária da Vale S/A, responsável pela barragem que rompeu em Mariana, Minas Gerais, começou a veicular uma peça publicitária no horário nobre em diversas emissoras de TV do país, tentando mostrar o "outro lado" da empresa, que tenta recuperar as águas do Rio Doce e amenizar os efeitos do desastre. Em um determinado momento dessa peça publicitária, um funcionário da empresa diz: "de repente a gente amanheceu com essa missão de ajudar as pessoas", como se a responsabilidade pelo ocorrido não fosse da Samarco S/A. Contudo, o efeito entre os telespectadores foi exatamente o contrário. O tom de crítica entre os usuários do Twitter, por exemplo, chegou quase à unanimidade entre todos os posts dessa rede social, que marcou um dos assuntos mais comentados na noite do dia 15 de fevereiro do 2016, quando a peça publicitária foi veiculada no intervalo do Jornal Nacional da Rede Globo, o que levou à sua suspensão. Para mais detalhes, vide a reportagem da redação da Revista Fórum, disponível em: https://www.revistaforum.com.br/segundatela/2016/02/16/samarco-tenta-melhorar-imagem-com-comercial-e-internautas-se-revoltam/.
\end{abstract}

2 O PublicEyeAwards é uma espécie de concurso organizado pelo Greenpeace da Suíça, com o apoio da ONG Declaração de Berna desde 2000, que se presta a escolher, por voto popular, a pior empresa do mundo. Para concorrer, a empresa tem que ter causado grandes impactos socioambientais. No ano em que a Vale S/A venceu, 2012, ela concorreu com a Tepco, a empresa japonesa responsável pelo desastre nuclear de Fukushima, que, ainda assim, levou menos votos que a empresa brasileira, devido à articulação de várias organizações e coletivos que fazem frente à mineração no Brasil e no mundo, com destaque, a International Network of People Affectedby Vale, a Rede Justiça nos Trilhos, a AmazonWatch e o Movimento Xingu Vivo para Sempre, que comemoraram o resultado pelo fato de a Vale S/A ser uma empresa de nível multinacional presente, na época, em 38 países, com impactos socioambientais transfronteiriços, a exemplo da Hidrelétrica de Belo Monte. Para muitos movimentos sociais, o "Nobel da Vergonha" dado à Vale S/A não representou só um "prêmio", mas sim a exposição da empresa brasileira aos olhos do mundo todo, a qual, em nome de seus interesses, já desalojou muitas comunidades, despojadas de suas terras, que ainda sofrem com perseguição política, ameaças por capangas e pistoleiros, ou exploração de sua força de trabalho sem o devido respeito aos seus direitos trabalhistas. Para mais detalhes, vide a reportagem da redação do Brasil de Fato, disponível em: https:// www.brasildefato.com.br/node/8687/. 
das grandes mineradoras com relação às suas ações de resistência.

É exatamente sobre algumas dessas estratégias e contraestratégias que este trabalho se propõe a debruçar, levantando e analisando dados, com o objetivo de verificar a intensidade de sua influência em face dos conflitos relacionados ao setor de mineração do Brasil.

Para tanto, primeiro se situará o problema a partir da compreensão do modo como se põe em prática a atividade de extração de minérios no país. Em seguida, a atenção se dirigirá aos conflitos decorrentes dessa atividade, de modo a se ter uma vaga ideia a respeito de toda a tensão existente entre os diferentes agentes que os compõem. Por fim, serão abordados alguns dos movimentos sociais que fazem frente às grandes mineradoras, analisandoos através das suas próprias estratégias e contraestratégias, principalmente aquelas relacionadas ao novo marco regulatório da mineração elaborado pelo Governo Dilma, e às medidas provisórias do setor recentemente editadas pelo Governo Temer

A pesquisa realizada para o desenvolvimento deste trabalho consistiu, em um primeiro momento, na busca de estudos publicados na plataforma Scientific Electronic Library Online (SciELO), a partir das palavras-chave pré-definidas: "mineração", "impactos socioambientais" e "movimentos sociais", selecionadas depois da leitura de seus respectivos resumos que apresentassem alguma pertinência direta com o tema a ser abordado. Somaram-se a esses estudos os relatórios referentes ao setor, publicados pelo antigo Departamento Nacional de Produção Mineral (DNPM), substituído pela Agência Nacional de Mineração (ANM), recentemente instituída pela Lei n. 13.575 de 2017.

Já em um segundo momento, através de sites especializados na área, buscou-se identificar as organizações não governamentais e coletivos despersonalizados que dão corpo a alguns dos movimentos sociais que fazem frente às grandes mineradoras no Brasil, selecionando-se aqueles que listam algumas de suas principais estratégias e contraestratégias, seja por meio de reportagens, panfletos ou de publicações mais elaboradas.

\section{SITUANDO O PROBLEMA DA ATIVIDADE DE EXTRAÇÃO DE MINÉRIOS NO BRASIL}

O Brasil é um dos países mais ricos em diversidade geológica do mundo, tendo, por exemplo, a maior reserva de nióbio $(88,3 \%)$, a segunda maior reserva de caulim $(4,1 \%)$, a terceira maior reserva de bauxita 
$(12,2 \%)$, a quinta maior reserva de ferro $(8,3 \%)$, e a sexta maior reserva de estanho $(7,5 \%)$ das jazidas existentes. Isso sem levar em consideração o petróleo, que apresenta particularidades próprias e tratamento jurídico específico ${ }^{3}$, e uma grande variedade de outros tipos de minérios, metálicos ${ }^{4}$ e não metálicos ${ }^{5}$, cuja extração representa consideravelmente o setor na economia nacional, que, só no primeiro semestre de 2017, segundo o I Informe Minerário (2017, p. 2 e 5-6) publicado pelo DNPM referente a esse mesmo período, atingiu um crescimento de $5,5 \%$ em comparação com o primeiro semestre de 2016, e que foi responsável por U\$14,7 bilhões das exportações do país, destinadas, em grande parte, para a China $(41,8 \%)$, Japão (5,9\%), Países Baixos (5,7\%), Estados Unidos (5,6\%), Malásia $(4,7 \%)$, Inglaterra $(3,1 \%)$, Índia $(2,6 \%)$, Coréia do Sul $(2,6 \%)$, Alemanha $(2,5 \%)$ e Suíça $(2,5 \%)$.

O Brasil é o quinto maior extrator de minérios do mundo todo, tendo destaque no primeiro semestre de 2017, segundo o I Informe Minerário (2017, p. 5), a produção de ferro (U\$ 10,05 bilhões), ouro (U\$ 1,3 bilhões), cobre (U\$ 1,08 bilhões), ferro nióbio (U\$ 7,7 milhões), manganês (U\$ 143,8 milhões), alumínio (U\$ 108,7 milhões) e caulim (U\$ 97,5 milhões). O Sudeste (representado por Minas Gerais), logo em seguida o Norte (representado pelo Pará), são as principais regiões de extração de minério do país, onde a arrecadação da Compensação Financeira por Exploração de Recursos Minerais (CFEM) marca os maiores valores ${ }^{6}$.

Sem levar em consideração pequenas e médias mineradoras, ou, ainda, os garimpos ilegais, ao todo, os empreendimentos instalados e em operação em todo o Brasil empregam diretamente um total superior, segundo o I Informe Minerário (2017, p. 7-9), a 165 mil pessoas, dos quais $49,9 \%$ se concentram no Sudeste e apenas $14,4 \%$ no Norte. Só na Amazônia, mais especificamente, existem 52 grandes mineradoras com

3 Por essa razão, embora seja um recurso mineral, inclusive muito importante para o Brasil, o petróleo não constituirá o objeto de análise deste trabalho.

4 Destacam-se entre os metais metálicos, a bauxita, o estanho, o cobre, o minério de manganês, o chumbo, o zinco, o níquel, o vanádio, o ouro, a prata e a platina.

5 Já entre os minérios nãometálicos, destacam-se a pedra, a areia, a argila, o mármore, o granito, o calcário, a dolomita, o gesso e o caulim.

6 Com previsão no art. 20, $\S 1^{\circ}$ da Constituição de 1988, a CFEM trata de um royalty devido aos estados, ao Distrito Federal, aos municípios, e aos órgãos da administração da União, como contraprestação pela exploração econômica dos recursos minerais em seus respectivos territórios, cuja base de cálculo, até as medidas provisórias do setor recentemente editadas pelo Governo Temer, incidia sobre o faturamento líquido de quem os explorasse, numa alíquota que variava de $0,2 \%$ a $3 \%$, a depender do minério. Segundo o I Informe Minerário (2017, p. 10-11), só no primeiro semestre de 2017, foram arrecadados quase R $\$ 921$ milhões a título de CFEM, um aumento de 18,1\% com relação ao mesmo período do ano anterior. Desse total, 44,1\% correspondia à exploração dos recursos minerais em Minas Gerais, logo seguido pelo Pará, cuja exploração correspondeu a 37\% da CFEM de todo o país. 
algum empreendimento instalado e em operação até 2015, sendo a Vale S/A a maior entre elas, respondendo por $65,83 \%$ de toda a produção do setor só no Pará.

Diante de todos esses números, embora importantes para se compreender a força da atividade de extração de minérios na economia nacional e da importância do Brasil para o mercado mundial, fica difícil saber o que está por trás de tudo isso.

Talvez, compreender a formação histórica do processo de extração de minérios no Brasil seja a primeira maneira de se ter à mão um instrumento de esclarecimento a respeito dos interesses envolvidos nessa atividade, os quais costumam ficar escondidos atrás de um discurso desenvolvimentista, típico de uma lógica estritamente mercadológica.

Tomando por base vários estudos da área, é comum que se dividaa extração de minérios no Brasil em três fases históricas, cada uma em função da maneira de pôr em prática essa atividade, o que obviamente está de acordo com os respectivos contextos sociais, políticos e econômicos de cada época, para as quais correspondeu um tratamento jurídico próprio ${ }^{7}$.

A primeira fase se refere ao ciclo do ouro de jazidas superficiais, que reestruturou fundamentalmente o mercantilismo ibérico no final do século XVII e início do século XVIII, a ponto de o Brasil ter deixado o status de mera governadoria-real para se tornar o vice-reino, por um decreto de 1720 da coroa portuguesa ${ }^{8}$.Já a segunda fase diz respeito ao ciclo do ouro de jazidas primárias, cuja extração foi financiada pelo capital estrangeiro, sobretudo o inglês, que começou a entrar no país com essa finalidade no início do século XIX, mas pouco tendo retorno lucrativo com

\footnotetext{
7 Nesse sentido, convergem os estudos de Guedes (2015, et seq.) e Kono (2014, et seq.).

$8 \mathrm{O}$ ciclo colonial do ouro se caracterizou pela extração desse e de outros metais preciosos, como o diamante, de jazidas superficiais, e que, por isso, não prescindiam exatamente de uma busca ativa no subsolo. Segundo os diversos historiadores citados por Guedes (2015, p. 7-10 e 22-26), os registros que se tem à disposição divergem entre si quanto à data e ao local da descoberta das grandes jazidas superficiais no Brasil, pois as narrativas tradicionais e as correspondências oficiais trocadas entre as governadorias-reais da Bahia e do Rio de Janeiro só refletem os achados dos primeiros 10 anos, e, ainda assim, imprecisos e tardios. O que se sabe é que as campanhas dos bandeirantes no final do século XVII descobriram, quase que simultaneamente, várias jazidas superficiais de ouro e diamante na região que viria a se tornar Minas Gerais, às quais se seguiram outras descobertas, só que não tão importantes, em Pernambuco, Sergipe, Bahia e Espírito Santo. Desde então, prossegue a autora, iniciou-se uma exploração de larga escala do ouro de aluvião (aquele facilmente extraído), levando o Brasil a se tornar o maior produtor desse metal precioso no século XVIII e o primeiro produtor comercial de diamante, que até então só era extraído em pequenas quantidades na Índia. Nesse período, em média 1 milhão de quilos de ouro extraídos no Brasil foram registrados oficialmente, estimando-se ainda que, no mínimo, outro 1 milhão tenha sido contrabandeado, o que também ocorreu com a extração de diamantes, já que oficialmente foram registrados cerca de 2,4 milhões de quilates, sendo até hoje incalculável o montante contrabandeado desse metal precioso.
} 
o "fim" da escravidão em $1888^{9}$. Por último, a terceira fase, que se vê desde o início do século XX até os dias de hoje, está relacionada à extração de outros minérios que não apenas o ouro ${ }^{10}$ por grandes mineradoras,cuja atividade se presta a atender à demanda, sobretudo industrial,do mercado mundial, e sobre a qual existem subfases, que variam com as reviravoltas políticas ocorridas no país nesse período, principalmente durante e depois da ditadura militar.

É sobre essa terceira fase, chamada de neoextrativismo, que este trabalho situará cronologicamente o problema da atividade de extração de minérios no Brasil.

De acordo com o estudo desenvolvido por Guedes (2015, p. 1419), com a Revolução Industrial, a demanda pelos mais variados tipos de minérios cresceu no mundo todo, principalmente entre os países mais desenvolvidos (aqui chamados de Norte-Global), cujas minas já haviam chegado ao esgotamento. Essa demanda só aumentou com a primeira e a segunda guerra mundial, que levaram, por exemplo, ao estreitamento da relação dos Estados Unidos com o Brasil.

Os norte-americanos passaram afinanciar uma série de pesquisas no solo e no subsolo brasileiro à procura de quartzo piezoelétrico, manganês, zircônio, caulim e barita ${ }^{11}$. As descobertas decorrentes dessas pesquisas impulsionaram várias empresas multinacionais a comprar extensas áreas de terras no Brasil, instalando atividades de extração, beneficiamento e, obviamente, exportação de minérios. Isso tudo ainda "coincidiu"com a política de industrialização do país instituída pelo Governo Vargas, e que perdurou até o Governo Kubitschek, período em que foram criadas

\footnotetext{
9 Ainda com base nos estudos de Guedes (2015, p. 13 e 26), há registros históricos que indicam que o ciclo do ouro das jazidas primárias foi a fase de extração de metais preciosos iniciada em 1824 por empresas inglesas, como a The Ouro Preto Gold Mines of Brasil Ltd. (Mina da Passagem), a St. John del Rey Gold Mines Co. (Mina do Morro Velho) e a São Bento Gold StatesLtd. (Mina Santa Bárbara) que, ainda sustentadas pela mão de obra escravizada, passaram a utilizar técnicas mais sofisticadas, mas, nem por isso menos destrutivas, de exploração do subsolo, a exemplo do uso da pólvora, dinamite, força hídrica para drenagem, ventilação de mina, além de técnicas de "purificação" dos metais preciosos, como a amalgamação por mercúrio, que é uma técnica muito perigosa para asaúde humana de quem a manuseia.

10 Desde a colônia já se extraíam outros minerais que não o ouro ou o diamante, a exemplo do ferro. Uma carta de José de Anchieta, datada de 1554, já dá conta da extração de ferro no Brasil nesse período. Segundo Guedes (2015, p. 9), uma fábrica catalã foi instalada em Araiçoaba, próximo a Sorocaba, em São Paulo, para fabricação de instrumentos simples para uso doméstico ou na agricultura.

11 Além desses, Scliar (1996, p. 83) diz que o território brasileiro foi esquadrinhado por geólogos norte-americanos com o objetivo de encontrar minérios, a exemplo do nióbio, do tântalo, do tungstênio, do berilo e do cristal de quartzo, para suprir a demanda por minérios da indústria bélica. Explicando o contexto, por exemplo, da descoberta da jazida de ouro em Carajás, no Pará, em 1962, por um geólogo a serviço da empresa norte-americana United States Steel, que já vinha promovendo pesquisas na área desde 1949.
} 
as grandes empresas públicas do setor devido ao fomento do mercado interno, as quais tinham como principal matéria-prima o ferro, o carvão e o petróleo ${ }^{12}$.

Ao longo das décadas de 1940 e 1950, o setor passa por uma reestruturação, que só se finaliza, segundo Guedes $(2015$, p. 16), na década de 1960, e, ainda assim, de maneira bastante diferenciada entre as principais regiões de extração de minérios do país (Sudeste e Norte), em função da chamada política de integração nacional adotada pela ditadura militar, que definiu, basicamente, o modelo atual dessa atividade, já que partes substanciais do Código de Mineração (Decreto-Lei n. 227 de 1967)em vigor datam desse período.

Kono (2014, et seq.) oferece um estudo mais detalhado sobre a política de integração nacional incidente na territorialidade da Amazônia, mais precisamente no Pará, onde se instalou a maior parte dos empreendimentos do setor, em meio ao que ele chama de "babel fundiária", que só contribuiu, ainda mais, para intensificar uma isonomia negativa com relação ao acesso à terra na região.

A "babel fundiária" no Pará resultaria de vários fatores, dos quais Kono (2014, p. 48) destaca: o traumático processo político-econômico de ocupação ${ }^{13}$; as desarticuladas políticas públicas de titulação das terras e os problemas de localização e de falsificação (grilagem) ${ }^{14}$; e a intervenção 12 Nesse contexto, diferentemente do que se supõe, Guedes $(2015$, p. 15) conta que um influente movimento, formado na década de 1930 por técnicos, empreendedores e diretores de entidades de classe de Minas Gerais, defendia que a industrialização do Brasil seria a saída de todo o atraso econômico amargado pelo setor, defendendo também que só a proteção da indústria nacional da entrada de capital estrangeiro seria capaz de mantê-la forte. Assim, principalmente no Governo Vargas, iniciou-se um intenso processo de implantação de empresas públicas voltadas para esse setor, a exemplo da Companhia Siderúrgica Nacional (CSN), instalada em Volta Redonda, no Rio de Janeiro, a partir da nacionalização de uma mina de ferro que pertencia à empresa alemã $A$. Thun, e da própria Companhia Vale do Rio Doce (CVRD), hoje Vale S/A. A Vale resultou da transferência para o patrimônio da União de uma mina de ferro, pertencente à empresa inglesa Itabira Iron Ore Co., situada em Itabira, Minas Gerais, tendo isso ocorrido para atender a uma das cláusulas do Acordo de Washington, firmado entre o Brasil, os Estados Unidos e a Inglaterra, em proveito da indústria bélica dos aliados.

13 Com relação a esse primeiro fator, Kono (2014, p. 48-56) esclarece que se costuma dividir a ocupação no Pará em quatro fases: a dos povos ameríndios, muito antes da chegada dos europeus às Américas; bem depois, a dos portugueses, ocupando, sobretudo, as margens dos rios; a dos nordestinos, com o objetivo de trabalhar nos seringais nos tempos do auge da borracha; e a dos imigrantes, com destaque aos nordestinos mais uma vez, depois dos investimentos do capital, a partir da década de 1960 até os dias atuais. As três primeiras fases contribuíram fundamentalmente para a formação do campesinato tradicional amazônico cabloco, produto da miscigenação entre indígenas, negros, nordestinos seringueiros e outros forasteiros, que se organizavam em sociedades comunais baseadas no trabalho familiar, na agricultura de subsistência e no extrativismo animal e vegetal, cujos frutos do labor pertenciam a todos.

14 Quanto ao segundo fator, Kono (20114, p. 56-73) primeiro explica que as desarticuladas políticas públicas de titulação de terras no Pará estão, a princípio, em função dos mais de 24 tipos de documentos fundiários expedidos ao longo da história do Brasil, cada um de acordo com os seus respectivos tratamentos jurídicos, próprios do regime em que foram expedidos, que variam entre o regime sesmarial 
federal decorrente, principalmente, da política de integração nacional da ditadura militar, levando à confusa gestão das terras públicas no estado.

O objetivo dessa política dependia do esvaziamento do poder de autoridades e oligarquias locais, concentrando nas mãos da União a gestão sobre as terras da região. Mas Kono (2014, p. 73) diz que isso só se tornou possível, de fato, a partir da Constituição de 1967, que possibilitou a intervenção federal em função da "defesa nacional" e do "desenvolvimento do país”.Extensas áreas de terra da Amazônia, principalmente do Pará, foram federalizadas a partir da edição do Decreto-Lei n. 1.164 de 1971, que as destinaria aos nordestinos então ocupantes das rodovias recémconstruídas (Belém-Brasília, Transamazônica, BR-230 e Pará-Maranhão) atraídos pela propaganda da ditadura militar.

Contudo, pode-se dizer que as terras federalizadas serviram mesmo ao capital que visava explorar os recursos florestais e minerais da Amazônia. Isso porque, grandes mineradoras, que já haviam iniciado a busca por minérios na Amazônia quase uma década antes ${ }^{15}$, então se instalaram na região com incentivos fiscais e crédito facilitado, obtendo o direito de extrair os mineiros de jazidas adquiridas segundo as regras do Código de Mineração então aprovado.

\section{OS CONFLITOS DECORRENTES DA EXTRAÇÃO DE MINÉRIOS NO BRASIL}

Encarando a atividade de extração de minérios no Brasil por outra lógica que não aquela estritamente mercadológica, típica do discurso desenvolvimentista que se costuma ouvir com mais frequência, toda a tensão entre os diferentes agentes que a compõem fica mais tangível, a ponto de se olhar com outras lentes os conflitos decorrentes dessa

(1500-1821) e o de posses (1821-1850), e entre o regime da Lei de Terras (1850-1889) e o republicano (1889 aos dias atuais). Além dessa grande diversidade de documentos fundiários, ainda existem outros problemas que levam às desarticuladas políticas de titulação de terras no Pará, como é o caso dos títulos imprecisos (geralmente pela ausência de informações técnicas de caráter cartográfico, que impedem a identificação e a localização da terra correspondente), e dos títulos falsos decorrentes do processo que se habituou chamar de grilagem. Para se ter uma vaga noção do fenômeno da grilagem no Pará, uma pesquisa realizada pelo extinto Ministério da Política Fundiária e do Desenvolvimento Agrário (MPFDA) identificou que dos mais de 100 milhões de hectares de área grilados em todo o Brasil, 30\% se encontravam só no Pará. A respeito da grilagem, vide a publicação de um grupo de trabalho criado pelo Ministério do Meio Ambiente (MMA) para estudar esse fenômeno na Amazônia: BRASIL. Ministério do Meio Ambiente. A Grilagem nas terras públicas da Amazônia brasileira. IPAM: Brasília: MMA, 2006.

15 Entre 1953 e 1959, descobriu-se ouro na região do Tapajós, no Pará (depois na região da Serra Pelada, também no Pará), somado à exploração da cassiterita no Município de Ariquemes, em Rondônia (e também, no Município de São Félix do Xingu, igualmente no Pará), causando uma explosão garimpeira na Amazônia, que funcionou como mais uma sedução migratória. 
atividade,que se desenvolveu ao longo da consolidação de uma histórica estrutura assimétrica de poder.

A respeito, Wanderley (2009, et seq.) esclarece que os conflitos como esses geralmente são analisados à luz da (in)justiça social no acesso aos recursos naturais, que, por serem finitos, não comportam a distribuição segundo um modelo baseado em concentração. Para ele (2009, 2-4), essa análise não serve para se compreender muitos dos aspectos de conflitos entre comunidades locais e grandes mineradoras, já que tais conflitos se desenvolvem em função da disputa pelo controle e gestão do território, e não exclusivamente pelos recursos naturais, cujo acesso, mais ou menos (in)justo,é só uma das consequências.

Assim, fica mais claro o porquê das comunidades locais, quando contrárias à instalação de grandes mineradoras, não quererem tomar o lugar delas na exploração do ferro ou da bauxita, já que não é necessariamente o minério que está em jogo, mas, sim, todos os impactos socioambientais que decorrem de sua extração e afetam o território no qual se trava a disputa ${ }^{16}$.

Obviamente é impossível tratar de todos os conflitos decorrentes da atividade de extração de minérios no Brasil no bojo deste trabalho. Por isso mesmo, selecionou-se o caso Onça Puma Ltda., que é relativamente recentee teve menos repercussão, para analisá-lo à luz do raciocínio indutivo, sem, contudo, ter a pretensão de generalizar os seus aspectos e impactos como se fossem comuns a todos os demais conflitos.

Em maio de 2011, o Ministério Público Federal (MPF) propôs Ação Civil Pública (ACP) pedindo à Justiça Federal a suspensão das atividades mineradoras da Onça Puma Ltda., uma subsidiária da Vale S/A, cujo empreendimento se situa no sudeste paraense, compreendendo a zona rural dos Municípios de Parauapebas, São Félix do Xingu e Ourilândia do Norte, de onde extrai níquel e o beneficia em uma usina metalúrgica instalada na região. Os depósitos do empreendimento ficam nas Serras do Onça e do Puma, que deram nome à subsidiária, área contígua à terra indígena dos Xikrin ${ }^{17}$.

16 Levando em consideração vários exemplos no Brasil, para Wanderley (2009, p. 6), os principais impactos socioambientais sobre o território causados pela atividade mineradora são: alterações no lençol freático; mudança na drenagem e esgotamento dos recursos hídricos; assoreamento de rios e nascentes; erosão; ameaça à biodiversidade local; desmatamento; poluição do solo e do ar; movimento de massas populacionais, tanto de pessoas atraídas pela atividade, quanto de pessoas despojadas do seu modo de vida, resultando em problemas sociais; além do desassossego que o buraco deixado na região após o abandono do empreendimento de extração causa na comunidade local; dentre tantos outros impactos socioambientais.

17 Para mais detalhes, consultar a movimentação do processo n. 0002383-85.2012.4.01.3905 no site do Tribunal Federal da $1^{\mathrm{a}}$ Região (TRF1), onde também constam alguns documentos disponíveis para 
Segundo ACP do MPF (2011, p. 2-3 e 39-40), essa terra indígena fica às margens do Rio Cateté, na bacia do Rio Xingu,e foi demarcada em 1981, mas homologada apenas em 1991, depois de quase dezessete anos de estudos, identificação e delimitação. Mesmo demarcada em mais de 430 mil hectares, uma importante área de caça e pesca tradicional das cabeceiras de um rio afluente, de quase 13 mil hectares, foi suprimida da demarcação, levando à indignação dos Xikrin que ainda a reivindicam. Hoje, osXikrin se dividem em três aldeias: Pukatingró (em média, 700 pessoas), Djudjekô (com mais 420 pessoas) e Oodjã (cerca de 175 pessoas).

Giannini (2001, não paginado) explica que a cosmologia dos Xikriné definida de acordo com a divisão do mundo em quatro espaços naturais distintos: o domínio do céu (o mundo que fica a Leste, o lugar de origem de todas as coisas); o domínio da terra, dividido em floresta (o mundo das relações agressivas, onde se desenvolvem a caça, a pesca e a guerra) e clareira (o mundo onde se neutralizam as relações agressivas, por meio da domesticação de plantas e animais, e onde se fixa a aldeia por ser o lugar em que as relações de parentesco são construídas); o domínio aquático (o mundo de fortalecimento do corpo e do espírito de qualquer um que se banha nas águas em rituais de submersão, que, além de curar, faz amadurecer, inclusive, os saberes);e o domínio subterrâneo (o mundo antissocial, onde se é a presa das larvas que se alimentam dos mortos).

Tal cosmologia está diretamente relacionada à maneira como os Xikrin vêm lidando com a instalação e a operação da grande mineradora confinante às suas terras. A cava (abertura de minas), por exemplo, significa a própria abertura do domínio subterrâneo, que coloca sobre o domínio da terra maus agouros.

\section{Mas vai muito além.}

Um estudo técnico elaborado em 2011, um pouco antes do ajuizamento da ACP pelo MPF, constatou concentração de níquel superior ao nível permitido à segurança humana no Rio Cateté. Devido ao consumo da água contaminada, os Xikrin passaram a apresentar uma queda populacional por doenças gastrointestinais, além de casos de malformação entre os seus recém-nascidos, causando um grande impacto sobre suas crenças, já que era a doença que estava vindo do domínio aquático, e não a cura, como até então acreditavam.

Na ACP, oMPF (2011, 4-12) alegou que suas investigações preliminares o levaram à conclusão de que os órgãos ambientais do Pará visualização, disponível em:https://processual.trf1.jus.br/consultaProcessual/processo.php?proc $=0002$ 3838520124013905\&secao=RDO\&pg=1\&enviar=Pesquisar. 
haviam sido lenientes com a Onça Puma Ltda. Isso porque, em 2004, foi emitida a licença prévia para a subsidiária da Vale S/A, que tinha como contrapartida a apresentação de um plano de medidas para a prevenção, mitigação e compensação ao povo indígena confinante do empreendimento devido aos impactos socioambientais que este poderia vir a causar.

Em 2005, já com um esboço do plano exigido ${ }^{18}$, a Onça Puma Ltda. conseguiu a emissão da licença de instalação, que só foi seguido de um estudo etnoecológico financiado pela subsidiária da Vale S/A porque deveria apresentá-lo quando fosse requerer a emissão da licença de operação ${ }^{19}$. Em 2008, mesmo sem adotaras medidas necessárias para a prevenção, mitigação e compensação dos impactos socioambientais então previstas, a licença de operação foi emitida, e renovada dois anos depois, sem qualquer tipo de fiscalização por parte dos órgãos ambientais do Pará. Ou seja, por quase três anos, a extração de níquel na região não foi precedida por qualquer medida que, pelo menos, diminuísse o grande impacto socioambiental, em especial para os Xikrin, e que,ainda por cima,eram condicionantes à expedição e renovação das licenças.

Se nem mesmo as condicionantes à expedição e renovação das licenças foram observadas, muito menos houve a preocupação de se realizar a consulta prévia e informada aos Xikrin e às comunidades locais a respeito da instalação do empreendimento na região.

18 As medidas de prevenção, mitigação e compensação aos Xikrinpelos impactos socioambientais que seriam eventualmente causados referiam-se: à energia (sem maiores dados); ao esporte (sem maiores dados); à economia, por meio de parceria e comercialização de excedentes; à qualidade de água através da recuperação das matas ciliares; ao apoio, reforço e suporte à educação escolar; ao desenvolvimento institucional (sem maiores dados); à comunicação (sem maiores dados); aos controles de qualidade e vazão de água; ao controle de emissão de resíduos sólidos por ordenamento territorial; e à infraestrutura (sem maiores dados).

19 Elaborado por dois antropólogos, inclusive pela já citada Giannini (2001, et seq.), que já vinha desenvolvendo pesquisas etnográficas junto aosXikrin, o estudo etnoecológico constatou que esse povo conhece profunda e detalhadamente seu meio ambiente e o maneja com técnicas diversificadas e sofisticadas; além disso, mostrou que se constitui numa sociedade cuja subsistência tem alto grau de dependência em relação ao seu território e aos recursos naturais nele presentes, principalmente a daqueles do Rio Cateté. Na concepção dosXikrin, a floresta, os rios, o solo e a natureza não são apenas "recursos naturais", mas a morada de inúmeros seres sobrenaturais e entidades determinantes para o bem-estar social. São esses seres que definem, por exemplo, a saúde e a doença, a vida e a morte. Perturbações ao meio ambiente representam, portanto, não só problemas de ordem física, mas também espiritual, explicando muitas das preocupações de diferentes pessoas desse povo. O estudo etnoecológico consignou algumas dessas preocupações, principalmente quanto à intensificação do confinamento da terra indígena, por meio do estrangulamento territorial, principalmente pelo cercamento, cada vez maior, da área já demarcada, por empreendimentos e ocupações nãoindígenas de alta transformação ambiental, que ainda leva a episódios de invasões, e bem assim, aos impactos reais e potenciais sobre o Rio Cateté. Além desses impactos,ocorrem outros possíveis danos socioambientais, tais como a intensificação de ruídos e a poluição do ar, especialmente em decorrência da localização da usina metalúrgica, por esse povo considerada muito próxima, e ao estresse entre os Xikrindevido à incerteza e aos medos das consequências físicas e simbólicas decorrentes da atividade de extração de minérios pela subsidiária da Vale S/A. 
Liminarmente, a Justiça Federal suspendeu as atividades da Onça Puma Ltda., mas não deferiu o pedido feito pelo MPF para que a subsidiária da Vale S/A pagasse, mensalmente, para cada uma das três aldeias dos Xikrin, R\$ 1 milhão de reais, até que medidas necessárias para a prevenção, mitigação e compensação dos impactos socioambientais fossem efetivamente adotadas. A decisão liminar levou a uma batalha judicial que se encerrou em 2017, permitindo a continuidade regular do processo $^{20}$.

Casos como o da Onça Puma Ltda., nos quais o território é alvo de disputa entre grandes mineradoras e comunidades locais, são múltiplos pelo Brasil afora, e podem vir a ser cada vez mais frequentes ${ }^{21}$. Só no Pará, por exemplo,existem inúmeros pedidos de lavra de minérios, inclusive já concedidos, que incidem sobre terras indígenas ou território de outras comunidades locais.

20 Contra o capítulo da decisão liminar que não deferiu o pedido de R\$ 1 milhão ao mês para cada aldeia dosXikrin, o MPF e a Associação Indígena Bayprãinterpuseram agravo de instrumento à segunda instância da Justiça Federal, recurso no qual o relator concedeu a liminar in totum, levando, dessa vez, a Vale S/A a impetrar Mandado de Segurança ao presidente do TRF1 que, ao analisar a questão, suspendeu a decisão do relator do agravo de instrumento. Contra essa decisão proferida em Mandado de Segurança, o MPF, mais uma vez, com o apoio da Associação Indígena Bayprã, interpôs recurso ordinário ao Superior Tribunal de Justiça (STJ), que, por sua vez, suspendeu a decisão do presidente do TRF1 para repristinar a decisão do relator do agravo de instrumento. A Vale S/A então se utilizou de um supedâneo recursal para manter as atividades da Onça Puma Ltda., e, com o apoio do próprio Governo do Pará, ajuizou no Supremo Tribunal Federal (STF), em 2015, uma ação autônoma chamada de Suspensão de Liminar, cujo fundamento se origina da época da ditadura militar.Na Suspensão de Liminar, o Ministro Ricardo Lewandowski permitiu a continuidade das atividades da Onça Puma Ltda., o que foi objeto de um agravo regimental interposto pelo MPF e pela Associação Indígena Bayprã. O caso então entrou na pauta do plenário do STF em 2016, mas o seu julgamento foi suspenso pelo pedido de vista do Ministro Luís Roberto Barroso que, em 2017, o devolveu ao plenário para encabeçar a divergência seguida pela maioria, no sentido de fazer valer a decisão do relator do agravo de instrumento julgado na segunda instância da Justiça Federal, suspendendo as atividades da Onça Puma Ltda. e, ainda, com a obrigação de pagar, mensalmente, R\$ 1 milhão para cada aldeia dosXikrin. Para mais detalhes, vide a reportagem da imprensa oficial do Supremo Tribunal Federal sobre a decisão do plenário na SL n. 933, disponível em: http://www.stf.jus.br/portal/cms/verNoticiaDetalhe. asp? idConteudo $=345183 \&$ caixaBusca $=\mathrm{N}$.

21 Um caso muito parecido, e que hoje apenas se assiste às tristes consequências, diz respeito às marisqueiras de Santo Amaro, na Bahia. Segundo a pesquisa etnográfica desenvolvida por Barreto e Freitas (2017, et seq.), a tradicional atividade de captura de mariscos de mangue, tanto para o consumo da própria comunidade das marisqueiras, quanto para a venda no litoral, sofreu fortes impactos depois da poluição dos rios e até mesmo do mangue, causada por uma empresa de papel e por uma mineradora, tendo essa última, inclusive, despejado resíduos sólidos altamente tóxicos, como o chumbo, nesse ambiente. Isso levou a uma grave crise de incerteza alimentar (fome) para essa comunidade tradicional, além de problemas de saúde. 


\section{AS ESTRATÉGIAS E AS CONTRAESTRATÉGIAS DOS MOVIMENTOS SOCIAIS FRENTE ÀS GRANDES MINERADORAS NO BRASIL}

Analisando alguns sites especializados na área, a impressão que se tem é de que muitos movimentos sociais (de comunidades locais, de trabalhadores do setor ou de outros que acabam sendo afetados, de ativistas pelo meio ambiente, de pesquisadores ou de até certos partidos políticos) falam da mesma questão (os conflitos decorrentes da atividade de extração de minérios) de diferentes formas.

Os movimentos sociais ganham corpo através de organizações não governamentais e coletivos despersonalizados que definem um objeto de atuação específica, geralmente mais abstrato, ou um rol de objetivos em comum, tornando a pauta de reivindicação mais concreta, o que obviamente repercute sobre as suas estratégias e contraestratégias de atuação.

As estratégias e contraestratégias vão muito além de bloquear estradas ou ruas de grande tráfego, e podem ser muito mais difíceis, do ponto de vista do próprio marketing, para as grandes mineradoras lidarem, como foi com a Vale S/A ao ter recebido o "Nobel da Vergonha" em 2012.

Um exemplo é a recente estratégia do Movimento pela Soberania Popular na Mineração (MAM) de mobilizar diversas comunidades confinantes de empreendimentos instalados por grandes mineradoras, através da sensibilização de um documentário, lançado no último dia 22 de dezembro de 2017, no site desse movimento e na comunidade de Bandarro, no Ceará. No documentário, são retratados alguns impactos socioambientais sofridos diretamente por essa comunidade, sobretudo aqueles relacionados à água do Rio Poty, situado nesse mesmo estado, em razão da extração de ferro pela Globest Participações Ltda., que ainda continua em operação mesmo depois das suas licenças terem sido suspensas pelo órgão ambiental do Ceará, e após ter sido condenada pela prática de crime ambiental contra vegetação de preservação permanente ${ }^{22}$.

22 Outros fatos que chamam atenção quanto ao caso Globest Participações Ltda. diz respeito aos prejuízos causados à saúde da comunidade de Bandarro, sobretudo pela presença de uma densa poeira que vem causando problemas respiratórios e alergias entre os mais jovens e, também, às oportunidades de emprego, já que apenas sete dos 283 funcionários dessa grande mineradora vêm da comunidade, que, ainda por cima, nem sequer trabalhavam de carteira assinada (registros do Ministério do Trabalho e Emprego apontam que apenas 28 funcionários tiveram a carteira assinada). Para assistir ao documentário Sertão de Inhamuns: mineração e destruição, vide o site do MAMou o site do YouTube, respectivamente disponíveis em: http://mamnacional.org.br/2017/12/22/video-destaca-a-contradicao-entre-oterritorio-campones-e-a-industria-mineral/ e https://www.youtube.com/watch? $\mathrm{v}=\mathrm{hNUZ2-5ZKxI}$. 
Outra estratégia de natureza semelhante diz respeito às publicações da Rede Justiça nos Trilhos, a exemplo: da revista Não Vale ${ }^{23}$, que já está em sua terceira edição; dos relatórios anuais Insustentabilidade da Vale ${ }^{24}$; da cartilha Que Trem é Esse? ${ }^{25}$; e de outras publicações temáticas, como os recentes lançamentos Violações de direitos humanos na siderurgia: o caso TKCSA, Desastre no Vale do Rio Doce: antecedentes, impactos e ações sobre a destruição e Suspensão de segurança, neodesenvolvimentismo e violação de direitos humanos no Brasil ${ }^{26}$. Essa mesma estratégia também é assumida pela Justiça Global que já publicou inúmeros estudos ${ }^{27}$.

A tabela abaixo elenca as organizações não governamentais e coletivos despersonalizados que mais divulgam suas estratégias e contraestratégias em seus próprios sites (ou páginas oficiais em redes sociais como o facebook, além de blogs afins), especificando as suas principais frentes de resistência. Com relação aos movimentos sociais cujo objeto de atuação não diz respeito apenas aos impactos socioambientais decorrentes da atividade de extração de minérios, foram selecionadas as suas respectivas frentes de resistência a partir dos resultados decorrentes da pesquisa pela palavra-chave "mineração".

23 A revista Não Vale é uma publicação bianual, organizada pela Rede Justiça nos Trilhos. Nasceu da necessidade de divulgar os impactos negativos da mineração no Corredor Carajás, dando voz, principalmente, às comunidades atingidas pela Vale S/A. Na terceira edição, a revista traz artigos e reportagens sobre a resistência das comunidades e sobre os impactos negativos do projeto S11D, como atropelamentos e criminalização de lideranças locais. A revista se encontra disponível em PDF no site da Rede Justiça nos Trilhos, disponível em:http://justicanostrilhos.org/2017/02/10/revista-nao-vale-iiiedicao/.

24 Produzidos em parceria com a International Network of People Affectedby Vale, os relatórios anuais Insustentabilidade da Vale se prestam a dar visibilidade aos conflitos decorrentes da atividade de extração de minérios desenvolvida pela Vale S/A nos diferentes países onde essa grande mineradora opera. O relatório de 2015, por exemplo, dentre os dados desanimadores que traz sobre os impactos socioambientais, ainda aborda a suposta espionagem que a Vale S/A promove em relação a sindicatos e movimentos sociais. Esse relatório, especificamente, está disponível em PDF, em português, espanhol e inglês, no site da Rede Justiça nos Trilhos, disponível em: http://justicanostrilhos.org/2015/06/01/relatorio-de-insustentabilidade-da-vale-2015-2/.

25 A cartilha Que Trem é Esse?tem por finalidade: divulgar, de fácil compreensão, informações sobre os incômodos, danos e conflitos causados nas comunidades pela Vale S/A; orientar as comunidades sobre como se organizarem para não serem enganadas pelas promessas da grande mineradora e acabarem sofrendo ainda mais, e partilhar experiências positivas de comunidades ou pessoas que lutaram e conseguiram manter seus direitos garantidos. A cartilha não se encontra disponível no site da Rede Justiça nos Trilhos.

26 Todas essas publicações, além de muitas outras, estão disponíveis no site da Rede Justiça nos Trilhos: < http://justicanostrilhos.org $>$.

27 Algumas das publicações estão disponíveis em PDF no site do Justiça Global: <http://www.global. org.br/blog/category/biblioteca/biblioteca/>. 


\section{Tabela 1: Estratégias e contraestratégias de movimentos sociais frente às grandes mineradoras no Brasil.}

\begin{tabular}{|c|c|}
\hline Organização ou coletivo & Frentes de resistência \\
\hline $\begin{array}{l}\text { Central Única dos Trabalhadores } \\
\text { (CUT) }\end{array}$ & $\begin{array}{l}\text { Debates institucionais entre os sindicatos do setor, pressão por } \\
\text { fiscalização e apurações imediatas quanto às violações dos direitos } \\
\text { dos trabalhadores de grandes mineradoras, acompanhamento e } \\
\text { apoio a paralisações e greves. }\end{array}$ \\
\hline $\begin{array}{c}\text { Comitê Mineiro em Defesa dos } \\
\text { Territórios e do Mundo Natural Frente à } \\
\text { Mineração }\end{array}$ & $\begin{array}{l}\text { Representações contra empreendimentos de grandes mineradoras, } \\
\text { com base em estudos técnicos, a órgãos de controle, em especial, } \\
\text { ao Ministério Público. }\end{array}$ \\
\hline $\begin{array}{l}\text { Comissão Pastoral da Juventude } \\
\qquad(\mathrm{CPJ})\end{array}$ & $\begin{array}{l}\text { Realização de encontros da juventude atingida pela mineração } \\
\text { no Pará e no Maranhão, reunindo mais de } 100 \text { jovens ativistas e } \\
\text { integrantes entre as } 120 \text { comunidades que sofrem com impactos } \\
\text { decorrentes da atividade mineradora, principalmente com a Estrada } \\
\text { de Ferro Carajás. Nesses encontros, ocorrem debates, oficinas, } \\
\text { peças teatrais críticas e marchas com bandeiras e cartazes pelas ruas } \\
\text { das cidades sedes dos encontros. }\end{array}$ \\
\hline $\begin{array}{l}\text { Comissão Pastoral da Terra } \\
\text { (CPT) }\end{array}$ & $\begin{array}{l}\text { Promove um dos estudos mais completos sobre conflitos e } \\
\text { violações de direitos humanos no campo, incluindo os decorrentes } \\
\text { da atividade mineradora. Não existem maiores informações sobre } \\
\text { as frentes de resistência com relação a esse setor, embora seus } \\
\text { estudos sirvam para outros movimentos sociais. }\end{array}$ \\
\hline $\begin{array}{l}\text { Federação de Órgãos para Assistência } \\
\text { Social e Educacional } \\
\text { (FASE) }\end{array}$ & $\begin{array}{l}\text { Organização de eventos e oficinas sobre os impactos socioambientais } \\
\text { decorrentes da atividade mineradora, com a parceria de centros de } \\
\text { pesquisa universitários, realizando a publicação de artigos e demais } \\
\text { produções científicas sobre a questão, que podem ser encaminhados } \\
\text { ao e-mail de quem se cadastrar no site para receber informativos a } \\
\text { respeito. }\end{array}$ \\
\hline Fórum Carajás & $\begin{array}{l}\text { Promoção de estudos técnicos, inclusive com o apoio de parceiros } \\
\text { internacionais, sobre empreendimentos do Projeto Grandes Carajás, } \\
\text { que tenham influência não só no Pará, mas também no Maranhão } \\
\text { e Tocantins, usados para a sensibilização da opinião pública, } \\
\text { formação de lideranças locais, intervenção qualificada em políticas } \\
\text { públicas relacionadas a esses empreendimentos e em audiências } \\
\text { realizadas entre órgãos e instituições públicas, bancos e grandes } \\
\text { mineradoras para possibilitar debates e negociações. }\end{array}$ \\
\hline $\begin{array}{l}\text { Instituto Brasileiro de Análises Sociais e } \\
\text { Econômicas } \\
\text { (IBASE) }\end{array}$ & $\begin{array}{l}\text { Organização da agenda de vários eventos locais e nacionais } \\
\text { sobre a atividade mineradora, além da participação em eventos } \\
\text { estrangeiros e internacionais realizados por outros movimentos } \\
\text { sociais. Reconhecimento e valorização de grupos vulnerabilizados, } \\
\text { a exemplo das mulheres do campo, como resistência às grandes } \\
\text { mineradoras. }\end{array}$ \\
\hline $\begin{array}{l}\text { Instituto Socioambiental } \\
\text { (ISA) }\end{array}$ & $\begin{array}{l}\text { Além de estudos antropológicos, principalmente entre os povos } \\
\text { indígenas, reunidos em publicações e no site reservado somente } \\
\text { a esses povos, abordando os impactos da atividade mineradora } \\
\text { sobre eles,também articula alianças entre movimentos sociais e } \\
\text { associações indígenas em defesa de rios e territórios. }\end{array}$ \\
\hline
\end{tabular}




\begin{tabular}{|c|c|}
\hline $\begin{array}{c}\text { International Network of People Affected } \\
\text { by Vale }\end{array}$ & $\begin{array}{l}\text { Por meio de relatórios e dossiês, cataloga os impactos } \\
\text { socioambientais causados pelas Vale S/A nos países onde essa } \\
\text { grande mineradora instala seus empreendimentos, realizando } \\
\text { encontros entre representantes de diversos movimentos sociais e } \\
\text { comunidades locais, a fim de colher falas para a construção de } \\
\text { uma narrativa comum sobre o agressivo modelo de extração } \\
\text { de minérios e, assim, traçar contraestratégias, principalmente } \\
\text { contra a cooptação de autoridades por parte da Vale S/A. Atos e } \\
\text { manifestações populares, já chegando a reunir representantes de até } \\
\text { doze países, na sede da Vale S/A, quando ocorre a reunião anual } \\
\text { dos acionistas (entre } 12 \text { a } 15 \text { de abril), para forçá-los a negociar a } \\
\text { partir da entrega dos relatórios e dossiês, que, no Brasil, também } \\
\text { costumam ser protocolados junto às Câmaras de Vereadores, } \\
\text { Assembleias Legislativas e Congresso Nacional. }\end{array}$ \\
\hline Movimento dos Atingidos por Barragens & $\begin{array}{l}\text { As barragens construídas em função da atividade mineradora, a } \\
\text { exemplo das que servem aos rejeitos de minério, entram na pauta } \\
\text { de reivindicação como qualquer outra barragem, cujos projetos } \\
\text { são questionados em articulação com movimentos sociais de } \\
\text { outros países, em razão da dimensão, não raro, interfronteiriça dos } \\
\text { impactos socioambientais reais e potenciais. }\end{array}$ \\
\hline $\begin{array}{l}\text { Movimento dos Trabalhadores Rurais } \\
\text { Sem Terra } \\
\text { (MST) }\end{array}$ & $\begin{array}{l}\text { Ocupação de empreendimentos de grandes mineradoras, bloqueio } \\
\text { de ferrovias e minerodutos, apoio aos assentados da reforma agrária } \\
\text { ameaçados pela exploração de minérios, atos e manifestações } \\
\text { populares. }\end{array}$ \\
\hline $\begin{array}{l}\text { Sindicado dos Trabalhadores e } \\
\text { Trabalhadoras Rurais de Canaã dos } \\
\text { Carajás }\end{array}$ & $\begin{array}{l}\text { Boletim Informativo sobre a situação dos trabalhadores e } \\
\text { trabalhadoras rurais de Canaã dos Carajás, depois da instalação } \\
\text { dos empreendimentos das grandes mineradoras na região; parcerias } \\
\text { com pesquisadores das ciências sociais da Universidade Federal do } \\
\text { Pará e da Comissão Pastoral da Terra; realização de eventos locais, } \\
\text { com destaque ao I Encontro dos Atingidos pela Mineração em } \\
\text { Canaã dos Carajás, que discutiu o acompanhamento do processo de } \\
\text { reassentamento já em curso de famílias camponesas remanejadas, } \\
\text { a fim de que o acesso à terra dessas famílias seja garantido, } \\
\text { além de compensações através, por exemplo, da implementação } \\
\text { e melhoramento dos serviços públicos básicos, como saúde e } \\
\text { educação por parte das grandes mineradoras. }\end{array}$ \\
\hline Xô Mineradoras & $\begin{array}{l}\text { Utilizando redes sociais, publica uma série de fotografias, mapas, } \\
\text { charges, vídeos e reportagens com o objetivo de esclarecer àqueles } \\
\text { que seguem as suas páginas nessas redes sociais acerca dos impactos } \\
\text { socioambientais decorrentes da extração de minérios no Brasil, } \\
\text { e bem assim, o lobby que as grandes mineradoras desenvolvem } \\
\text { junto ao Congresso Nacional. Mantendo um link aberto para "bate- } \\
\text { papos", a exemplo do messenger do facebook, cria um canal direto } \\
\text { entre os ativistas, pesquisadores e qualquer interessado sobre o } \\
\text { assunto. }\end{array}$ \\
\hline
\end{tabular}

Fonte: Vide os sites (ou páginas oficiais em redes sociais como o facebook, além de blogs afins) listados nas "Referências".

Nota 1: Ao todo, foram levantadas 89 organizações não governamentais e coletivos despersonalizados com alguma relação a movimentos sociais frente à mineração no Brasil, dos quais 18 foram selecionados para estudo em razão da participação mais ativa na área, sem prejuízos de associações indígenas que acabam entrando 
na discussão quando em defesa das terras indígenas ante os interesses das grandes mineradoras.

Nota 2: Embora citadas como importantes parceiraspor muitos movimentos sociais frente à mineração no Brasil, algumas organizações nãogovernamentais, como a Associação para a Gestão Socioambiental do Triângulo Mineiro, a Conferência Nacional dos Bispos do Brasil (CNBB), Instituto Políticas Alternativas do Cone Sul (PACS), Instituto de Estudos Socioeconômicos (INESC) e Sociedade Paraense de Defesa dos Direitos Humanos; coletivos despersonalizados, a exemplo do Movimento Xingu Vivo para Sempre;sindicatos, com destaque ao Sindicato dos Petroquímicos do Paraná (SINDIQUÍMICA-PR); e partidos políticos, principalmente o Partido Socialista dos Trabalhadores Unificado (PSTU) não mantêm em seus sites (ou páginas oficiais em redes sociais como o facebook, além de blogs afins) informações mais detalhadas sobre as suas próprias frentes de resistência à atividade mineradora no país.

Nota 3: O site do Movimento pelas Águas e Serras de Minas, embora cite algumas de suas estratégias e contraestratégias, não conta com atualizações desde 2011, razão pela qual deixou de compor a tabela.

Nota 4: Por já terem sido citadas particularmente, não fizeram parte da tabela as estratégias e contraestratégias do Movimento pela Soberania Popular pela Mineração, da Rede Justiça nos Trilhos e da Justiça Global.

Talvez, dentre todas as estratégias, a mais ambiciosa tenha sido a criação do Comitê Nacional pela Defesa dos Territórios da Mineração (a partir de agora apenas Comitê), a respeito da qual Guedes (2015, et seq.), através de uma série de entrevistas realizadas com pessoas que desenvolviam algum tipo de secretariado no Comitê, levantou o maior número de informações disponíveis, considerando tratar-se de um coletivo despersonalizado, recentemente fundado, que reúne mais de 80 movimentos sociais frente à mineração, divididos entre organizações não governamentais, outros coletivos despersonalizados, sindicatos e partidos políticos $^{28}$.

Em entrevista a Guedes (2015, p. 109), Carlos Bittencourt, pesquisador e representante do IBASE no Comitê, esclareceu que, embora tenha sido fundado em 2013, o Comitê já vinha passando por um processo de construção ao longo de 2012, quando um grupo de trabalho constituído pelo IBASE, INESC, FASE e pela Rede Justiça nos $\operatorname{Trilhos}^{29}$ conseguiu 28 Todos os citados nesta seção fazem parte do Comitê.

29 Segundo a entrevista de JuliannaMalerba, assessora nacional e representante da FASE no Comitê, 
uma aproximação estratégica com Claudio Scliar, na época, Secretário de Geologia, Mineração e Transformação Mineral do Ministério de Minas e Energia, e sua assessora, Maria Amélia da Silva Enriques, responsáveis por desenvolver o esboço do projeto de lei que o Governo Dilma encaminharia com urgência constitucional ao Congresso Nacional para que o aprovasse como o novo marco da mineração no país ${ }^{30}$.

Só essa aproximação já foi uma conquista para os movimentos sociais, já que, até então, o desenvolvimento do esboço desse projeto de lei não tinha tido nenhuma participação popular, somente das grandes mineradoras $^{31}$. E mesmo que de início tenha sido fundado para investigar e discutir os motivos do aumento dos investimentos no setor, logo o Comitê passou a se ocupar, única e exclusivamente, com a democratização no processo de elaboração do novo marco da mineração ${ }^{32}$, que, no Congresso Nacional (Câmara dos Deputados), se tornou o PL n. 5.807 de $2013^{33}$.

concedidaa Guedes (2015, p. 109-110), o grupo de trabalho surgiu em 2008, quando várias comunidades locais passaram a procurar a FASE para noticiar os conflitos decorrentes da indústria siderúrgica e, eventualmente, da atividade mineradora. A FASE, então, passou a se articular com a Rede Justiça nos Trilhos e, juntas, realizaram uma série de caravanas norte-sul para identificar conflitos dessa mesma natureza, rendendo, por exemplo, a publicação do dossiê "Os impactos e violações da Vale no mundo" e a criação da International Network of People Affectedby Vale, num evento ocorrido em 2009. Para mais reflexões sobre o recente processo de expansão econômica da Vale S/A sobre minas de carvão em Moçambique, caracterizando o que passou a se chamar de subimperialismode países como o Brasil sobre o Sul-Global, ler a obra: SANTOS, Boaventura de Sousa; CHAUI, Marilena. Direitos humanos, democracia e desenvolvimento. São Paulo: Cortez, 2013.

30 Claudio Scliar, também em entrevista a Guedes (2015, p. 41 e 141) contou que, a pedido do Governo Dilma, ele e a sua assessora elaboraram o esboço de três projetos de lei, um para tratar do novo marco da mineração, propriamente dito, outro que dispusesse sobre a conformação do DNPM numa agência reguladora, e o último para regular os royalties, mas que, na Casa Civil, resolveram unificar num só.

31 Carlos Bittencourt, ainda em entrevista a Guedes (2015, p. 111), afirmou que o Comitê tentou obter uma cópia do esboço do projeto de lei do novo marco da mineração, antes do envio ao Congresso Nacional, mas, não obtiveram a permissão de Gilberto Carvalho, então Secretário-Geral da Presidência da República, e muito menos de Gleisi Hoffman, na época, Ministra da Casa Civil, para onde a Secretaria de Geologia, Mineração e Transformação Mineral do Ministério de Minas e Energia o havia encaminhado. Nas palavras dele: "Nós fizemos duas reuniões com Gilberto Carvalho. Depois, ele intermediou uma reunião com a Gleisi Hoffman. Na reunião, estavam presentes o MST e uma série de organizações, que são a base do Comitê. Foi uma reunião rápida. A gente apresentou as reivindicações. A principal reivindicação era: queremos ter acesso ao projeto, queremos debater. Ela disse que era impossível abrir a proposta, pois a democracia atrapalharia o conteúdo".

32 Até a fundação do Comitê pode ser considerada como uma estratégia. Carlos Bittencourt, em sua entrevista com Guedes (2015, p. 112-113), contou que foi necessário fazer a CNBB uma aliada a fim de torná-la o ponto de equilíbrio entre os diferentes movimentos sociais, já que a CNBB tinha influência tanto sobreos mais favoráveis ao Governo Dilma, quanto sobre os mais críticos. Hoje, a CNBB, além de compor o Comitê, ainda abriga a sede do secretariado em Brasília.

33 Fazendo uma comparação entre o então Código de Mineração e o PL n. 5.807 de 2013, uma das mudanças mais significativas diz respeito ao direito de exploração do subsolo, já que, pelo primeiro, era definido como direito de prioridade, uma espécie de ordem de chegada (quem primeiro requeresse a autorização de pesquisa, a primeira etapa do processo da autorização da lavra, teria direito a extrair os recursos minerais descobertos), enquanto pelo segundo, até as emendas do relator na Câmara dos Deputados e a exploração do subsolo, independentemente da autorização de pesquisa, seriam licitadas 
Desde então, o Comitê passou a se ocupar exclusivamente do novo marco da mineração. Tanto que, no Congresso Nacional, quando o Comitê já estava mais bem-estruturado, mostrou-se muito mais eficiente, a ponto de fazer o Governo Dilma retirar a urgência constitucional do PL n. 5.807 de 2013, permitindo a ampliação do debate.

O Comitê também representou o então relator do PL n. 5.807 de 2013, o Deputado Federal Leonardo Quintão, do Partido do Movimento Democrático Brasileiro de Minas Gerais (PMDB-MG), à Mesa Diretora da Câmara dos Deputados, por ele ter tido a campanha eleitoral financiada, em algo em torno de $\mathrm{R} \$ 400$ mil, por grandes mineradoras ${ }^{34}$.

Cogita-se aqui que o Comitê seja uma das mais ambiciosas estratégias frente à mineração no Brasil, pelo menos,por doismotivos: o primeiro está relacionado à força na sua representatividade, o que se deve ao grande número dos mais variados movimentos sociais frente às grandes mineradoras; e o segundo se refere aos objetivos comuns definidos por ocasião de um evento realizado na sede do Conselho Federal da Ordem dos Advogados do Brasil, em 2013, que levou à fundação do Comitể ${ }^{35}$, mostrando a capacidade de tornar a pauta de reivindicações locais em frentes de resistência nacionais, a ponto de fazê-las os interesses mais gerais de várias comunidades que sofrem com os impactos socioambientais decorrentes da exploração de minérios no país.

Mesmo com toda a assimetria na queda de braço, já que as grandes mineradoras sempre tiveram maior influência, tanto na elaboração do esboço do projeto de lei do novo marco da mineração, quanto nas emendas

(na modalidade chamada pública) para a assinatura de um contrato entre a União e aquele que apresentasse a melhor proposta. Outra mudança igualmente importante diz respeito à base de cálculo da CFEM, que então incidia sobre o faturamento líquido de quem desenvolvesse atividade mineradora, passando a incidir sobre o faturamento bruto, dando fim a uma série de divergências quanto ao que seria esse faturamento líquido. As alíquotas da CFEM também mudariam, deixando de ser variáveis entre $0,2 \%$ a $3 \%$ (a depender do minério), para ser até $4 \%$. Para mais detalhes sobre a CFEM, vide a nota de rodapé 8 deste artigo.

34 Para mais detalhes, vide a reportagem Macedo (2014, não paginado), disponível no site da Câmara dos Deputados: <http://www2.camara.leg.br/camaranoticias/noticias/POLITICA/467461-ALVO-DEREPRESENTACAO,-LEONARDO-QUINTAO-NEGA-IRREGULARIDADES-EM-CAMPANHAELEITORAL.html>.

35 Ao todo, o Comitê tem sete objetivos comuns a todas as organizações não governamentais, coletivos despersonalizados, sindicatos e partidos políticos que o compõem, a saber: garantir democracia e transparência na formulação e aplicação da política mineral brasileira; garantir o direito de consulta prévia e informada, além do consentimento e veto das comunidades locais afetadas pelas atividades mineradoras; respeitar taxas definidas de ritmos de extração de minérios; delimitar e respeitar áreas livres de qualquer tipo de mineração; controlar os danos ambientais e garantir planos de fechamento de minas com prévio contingenciamento de recursos; respeitar e proteger os direitos dos trabalhadores; e garantir que a mineração em terras indígenas respeite a Convenção n. 169 da Organização Internacional do Trabalho (OIT) e esteja condicionada à aprovação do Estatuto dos Povos Indígenas. 
parlamentares feitas ao PL n. 5.807 de 2013 no Congresso $\mathrm{Nacional}^{36}$, o Comitê vinha mostrando força na articulação insurgente de resistência ao modelo de mineração que se põe em prática no Brasil. Mas, com o Governo Temer, todo esse esforço caiu por água abaixo; pelo menos, era o que parecia.

Isso porque, em julho de 2017, às vésperas da votação da Câmara dos Deputados pela permissão da continuidade da denúncia proposta pela Procuradoria-Geral da República contra o Presidente da República, o Governo Temer lançou o Programa de Revitalização da Indústria Mineral Brasileira, que, através de três medidas provisórias,revogou o Código de Mineração em vigor desde a ditadura militar e, de forma unilateral, reestruturou boa parte das regras que regem a atividade mineradora no Brasil $^{37}$, ignorando totalmente o debate popular de quase seis anos, travado sobre a questão.

Como contraestratégia, o Comitê, que sequer foi convidado para a cerimônia de lançamento do Programa de Revitalização da Indústria Mineral Brasileira, à qual apenas autoridades e grandes mineradoras, além da imprensa, estavam presentes, passou a travar, por meio dos deputados federais aliados, a pauta do Congresso Nacional(Câmara dos Deputados), impedindo a aprovação, em tempo hábil, da principal medida provisória (Medida Provisória n. 790 de 2017, que alterava o Regime-Geral e o Regime-Especial de Exploração dos Recursos Minerais) editada pelo Governo Temer para o setor. Mantendo o antigo Código de Mineração parcialmente em vigor, o Comitê conseguiu devolvera discussão sobre a questão ao PL 5.807 de 2013, sobre o qual já existem outros vários projetos de lei apensados nas mais variadas direções ${ }^{38}$.

36 Isso pode ser facilmente constatado pelo número de audiências públicas realizadas pelo Congresso Nacional (Câmara dos Deputados) para discutir o PL n. 5.807 de 2013. Segundo Guedes (2015, p. 136137), das 17 audiências públicas, 6 discutiram questões ligadas diretamente à logística e ao proveito econômico do setor, enquanto apenas 3 foram reservadas para discutir os impactos socioambientais.

37 Medida Provisória n. 789 de 2017, que altera disposições sobre a CFEM (vide imagem 1 deste artigo), convertida pelo Congresso Nacional na Lei 13.540 de 2017; Medida Provisória n. 790 de 2017, que altera o Regime-Geral (minérios nãometálicos) e o Regime-Especial (minérios metálicos) de Exploração dos Recursos Minerais (vide notas de rodapé 6 e 7 deste artigo); e a Medida Provisória n. 791 de 2017, que cria a Agência Nacional de Mineração (ANM) e extingue o DNPM, mudando as regras de fiscalização do setor, convertida pelo Congresso Nacional na Lei n. 13.575 de 2017.

38 Nesse sentido, o Ato Declaratório n. 64 de 2017 da Presidência da Mesa do Congresso Nacional, o qual faz saber que a Medida Provisória n. 790 de 2017 teve seu prazo de vigência encerrado em 28 de novembro de 2017. 


\section{CONCLUSÃO}

Ao longo da pesquisa resultante deste trabalho, chegou-se a três conclusões a respeito das estratégias e contraestratégias dos movimentos sociais frente à mineração no Brasil.

A primeira conclusão se refere à forma como se compreende a atividade de extração de minérios desenvolvida no país. Isso porque, só tem como se dimensionar toda a tensão existente entre os diversos agentes desse campo, se o discurso desenvolvimentista, típico da lógica mercadológica, for deixado de lado, de modo a se perceber como os conflitos decorrentes da atividade mineradora se formam e se desenrolam ao longo da história do Brasil.

Já a segunda conclusão se dá em função do que, exatamente, pode ser considerado como o centro desses conflitos. Vários casos mostram que as comunidades locais afetadas por algum empreendimento de grandes mineradoras entram em disputa pelo controle e gestão do território como um todo, e não exatamente pelos recursos minerais, buscando deixá-lo a salvo dos mais diversos impactos socioambientais que são intrínsecos à maneira de pôr em prática essa atividade.

Por sua vez, a terceira conclusão está relacionada às frentes de resistência das várias organizações não governamentais e coletivos despersonalizados (incluindo também, em determinados casos, sindicatos e partidos políticos) que dão corpo a esses movimentos sociais. Existe uma série de frentes de resistências,umas mais locais, outras, regionais ou nacionais,que,através de estudos muito bem desenvolvidos, mobilização popular e articulação política, se prestam a desconstruir as "verdades" difundidas pelas grandes mineradoras, mostrando o quanto elas violam direitos humanos, principalmente daqueles que se encontram numa condição histórica e econômica de vulnerabilização.

\section{REFERENCIAS}

BARRETO, Mércia Ferreira; FREITAS, Maria do Carmo Soares. Segurança alimentar e nutricional e contaminação ambiental: tabu e estigma. Rio de Janeiro: Revista de Ciência \& Saúde Coletiva, n. 22(2), p. 527-534, 2017.

BLOG DO PEDLOWSKI. Comitê [Mineiro em Defesa dos Territórios e do Mundo Natural Frente à Mineração] quer proibir mineroduto da 
multinacional Angloamerican. Disponível em: <https://blogdopedlowski. com/2014/10/09/comite-quer-proibir-mineroduto-da-multinacionalangloamerican/>. Acesso: 19 dez. 2016.

BRASIL. Câmara dos Deputados. Projeto de Lei n. 5.807, de 19 de junho de 2013. Dispõe sobre a atividade de mineração, cria o Conselho Nacional de Política Mineral e a Agência Nacional de Mineração, e dá outras providências. Disponívelem: $<$ http://www.camara.gov.br/proposicoesWeb/ prop_mostrarintegra;jsessionid $=2089$ B79445251582A49F3A632DF474B C.proposicoesWebExterno 1 ? codteor $=1101841 \&$ filename $=\mathrm{PL}+5807 / 2013$ >. Acesso em: 11 dez. 2017.

BRASIL. Congresso Nacional. Ato Declaratório n. 64, de 6 de dezembro de 2017, da Presidência da Mesa do Congresso Nacional. Prazo de vigência encerrado da Medida Provisória n. 790, de 25 de julho de 2017, que altera o Decreto-Lei n· 227, de 28 de fevereiro de 1967 (Código de Mineração), e a Lei n 6.567, de 24 de setembro de 1978, que dispõe sobre regime especial para exploração e aproveitamento das substâncias minerais que especifica e dá outras providências. Disponível em: $<$ http://www.planalto. gov.br/ccivil_03/_Ato2015-2018/2017/Congresso/adc-064-mpv790.htm>. Acesso em: 30 dez. 2017.

BRASIL. Decreto-Lei n. 227, de 28 de fevereiro de 1967. Dá nova redação ao Decreto-Lei n. 1.985, de 29 de janeiro de 1940 (Código de Mineração). Disponível em: <http://www.planalto.gov.br/ccivil_03/decreto-lei/ Del0227.htm>. Acesso em: 11 dez. 2017.

BRASIL. Departamento Nacional de Produção Mineral. Anuário Mineral Estadual do Pará: 2016, ano base 2015. Brasília: DNPM, 2016.

BRASIL. Departamento Nacional de Produção Mineral. I Informe Minerário: 1\%2017. Brasília: DNPM, 2017.

BRASIL. Departamento Nacional de Produção Mineral. Programa de Revitalização da Indústria Mineral Brasileira[folder]. Brasília: DNPM, 2017.

BRASIL. Medida Provisória n. 789, de 25 de julho de 2017. Altera a Lei 
n. 7.990 , de 28 de dezembro de 1989, e a Lei n. 8.001, de 13 de março de 1990, para dispor sobre a Compensação Financeira pela Exploração de Recursos Minerais (CFEM). Disponível em: <http://www.planalto.gov. br/ccivil_03/_ato2015-2018/2017/Mpv/mpv789.htm>. Acesso em: $16 \mathrm{dez}$. 2017.

BRASIL. Medida Provisória n. 790, de 25 de julho de 2017. Altera o Decreto-Lei n 227, de 28 de fevereiro de 1967 (Código de Mineração), e a Lei n 6.567, de 24 de setembro de 1978, que dispõe sobre regime especial para exploração e aproveitamento das substâncias minerais que especifica e dá outras providências. Disponível em: $<$ http://www.planalto. gov.br/ccivil_03/_Ato2015-2018/2017/Mpv/mpv790.htm>.Acesso em: 16 dez. 2017.

BRASIL. Medida Provisória n. 791, de 25 de julho de 2017. Cria a Agência Nacional de Mineração e extingue o Departamento Nacional de Produção Mineral. Disponível em: <http://www.planalto.gov.br/CCIVIL_ 03/_Ato2015-2018/2017/Mpv/mpv791.htm>. Acesso em: 16 dez. 2017.

BRASIL. Ministério do Meio Ambiente. A Grilagem nas terras públicas da Amazônia brasileira. IPAM: Brasília: MMA, 2006.

BRASIL. Ministério Público Federal: Ação Civil Pública do Caso Onça Puma Ltda. Marabá: Procuradoria da República em Marabá, 2011.

BRASIL. Supremo Tribunal Federal. Supremo encaminha ação sobre projeto de mineração no Pará para instâncias anteriores. Brasília, 2017. Disponível em: $<$ http://www.stf.jus.br/portal/cms/verNoticiaDetalhe.asp?i $\mathrm{dConteudo}=345183 \&$ caixaBusca $=\mathrm{N}>$. Acesso em: 14 dez. 2017.

BRASIL DE FATO. Vale vence prêmio de pior empresa do mundo. Disponível em: $<$ https://www.brasildefato.com.br/node/8687/>. Acesso em 12 dez. 2017.

CENTRAL ÚNICA DOS TRABALHADORES. Mineração [palavra-chave]. Disponível em: <https://cut.org.br/busca/ ?q=minera $\% \mathrm{C} 3 \% \mathrm{~A} 7 \% \mathrm{C} 3 \% \mathrm{~A} 3 \mathrm{o}>$. Acesso em: $21 \mathrm{dez} .2016$. 
COMISSÃO PASTORAL DA JUVENTUDE. Mineração [palavra-chave]. Disponível em: <http://www.pj.org.br/2-encontro-da-juventude-atingidapela-mineracoma/>. Acesso em 17 dez. 2016.

COMISSÃO PASTORAL DA TERRA. Mineração [palavra-chave]. Disponível em: <https://cptnacional.org.br/component/search/ ?searchword $=$ mineração\&ordering $=$ newest $\&$ searchphrase $=$ all $>\quad$ Acesso em: 17 dez. 2017.

FACEBOOK. Fórum Carajás. Disponível em: <https://pt-br.facebook. com/forum.carajas>. Acesso em: 30 dez. 2016.

FACEBOOK. Xô Mineradoras. Disponível em: <https://www.facebook. com/xomineradoras>. Acesso em 30 dez. 2017.

FEDERAÇÃO DE ÓRGÃOS PARA ASSISTÊNCIA SOCIAL E EDUCACIONAL. Mineração [palavra-chave]. Disponível em: <https:// fase.org.br/pt/resultados-da-busca $/$ ?k $=$ minera $\% \mathrm{C} 3 \% \mathrm{~A} 7 \% \mathrm{C} 3 \% \mathrm{~A} 3 \mathrm{o} \& \mathrm{c}=>$. Acesso em 30 dez. 2017.

GIANNINI, Isabelle Vidal. KayapóXikrin: cosmologia. Instituto Socioambienal, 2001. Disponível em: $<$ https://pib.socioambiental.org/pt/ povo/xikrin-mebengokre/1633>. Acesso em: 28 dez. 2017.

GUEDES, Gisele Barbosa. Mineração e movimentos sociais. Dissertação: Mestrado em Ciências Sociais em Desenvolvimento, Agricultura e Sociedade. Universidade Federal Rural do Rio de Janeiro: Rio de Janeiro, 2015.

INSTITUTO BRASILEIRO DE ANÁLISES SOCIAIS E ECONÔMICAS. Mineração [palavra-chave]. Disponível em: <http://ibase.br/pt/ ?s=minera $\%$ C3\%A7\%C3\%A3o $>$. Acesso em:21 dez. 2017.

INSTITUTO SOCIOAMBIENTAL. Mineração [palavra-chave]. Disponível em: <https://www.socioambiental.org/pt-br/search/node/ mineração>. Acesso em 21 dez. 2017.

JUSTIÇA GLOBAL. Mineração [palavra-chave]. Disponível em: <http:// 
www.global.org.br/blog/category/biblioteca/biblioteca/>. Acesso em: 27 dez. 2017.

KONO, Bruno Yoheiji Ramos. A questão fundiária na Amazônia e os reflexos jurídicos no uso e ocupação do solo público pela mineração:estudo de caso do Estado do Pará. Dissertação: Mestrado em Direito. Pontífice Universidade Católica: São Paulo, 2014.

MACEDO, Idhelene. Alvo de representação, Leonardo Quintão nega irregularidades em campanha eleitoral. Brasília, 2014. Disponível em: $<$ http://www2.camara.leg.br/camaranoticias/noticias/POLITICA/467461ALVO-DE-REPRESENTACAO,-LEONARDO-QUINTAO-NEGAIRREGULARIDADES-EM-CAMPANHA-ELEITORAL.html>. Acesso em: 29 dez. 2017.

MOVIMENTO DEBATE E AÇÃO. Sindicato dos Trabalhadores e Trabalhadoras Rurais de Canaã dos Carajás lança boletim. Disponível em: $\quad<$ https://mineracaosudesteparaense.wordpress.com/2010/10/12/ sindicato-dos-trabalhadores-e-trabalhadoras-rurais-de-canaa-dos-carajaslanca-boletim-informativo/>. Acesso: 20 dez. 2016.

MOVIMENTO DOS ATINGIDOS POR BARRAGENS. Mineração [palavra-chave]. Disponível em: <http://www.mabnacional.org.br/search/ node/mineração>. Acesso em 21 dez. 2017.

MOVIMENTO DOS TRABALHADORES RURAIS SEM TERRAS. Mineração [palavra-chave]. Disponível em: $<$ http://www.mst.org.br/lutase-mobilizacoes/>. Acesso em: 21 dez. 2016.

MOVIMENTO PELASOBERANIAPOPULAR NAMINERAÇÃO. Vídeo destaca a contradição entre o território camponês e a indústria mineral. Disponível em: <http://mamnacional.org.br/2017/12/22/video-destaca-acontradicao-entre-o-territorio-campones-e-a-industria-mineral/>. Acesso em: 12 dez. 2017.

REDE JUSTIÇA NOS TRILHOS. Publicações. Disponível em: <http:// justicanostrilhos.org/category/publicacoes/>. Acesso em: 18 dez. 2017. 
REVISTA FÓRUM. Samarco tenta melhorar imagem com comercial e internautas se revoltam. Disponível em: $<$ https://www.revistaforum. com.br/segundatela/2016/02/16/samarco-tenta-melhorar-imagem-comcomercial-e-internautas-se-revoltam/>. Acesso em: 14 dez. 2017.

SANTOS, Boaventura de Sousa; CHAUÍ, Marilena. Direitos humanos, democracia e desenvolvimento. São Paulo: Cortez, 2013.

SCLIAR, Cláudio. Geopolitica das minas do Brasil. Rio de Janeiro: Revan, 1996.

VIVAT INTERNATIONAL. Justice on Tracks and the "Ist International Meeting of the People Affected by Vale". Disponível em: $\quad<$ http://www.microsofttranslator.com/bv.aspx?ref=SERP\&br=ro $\& \mathrm{mkt}=\mathrm{pt}-\mathrm{BR} \& \mathrm{dl}=\mathrm{pt} \& \mathrm{lp}=\mathrm{EN} \_\mathrm{PT} \& \mathrm{a}=\mathrm{http} \% 3 \mathrm{a} \% 2 \mathrm{f} \% 2$ fvivatinternatio nal.org $\% 2 \mathrm{fblog} \% 2 \mathrm{f} 2010 \% 2 \mathrm{f} 06 \% 2 \mathrm{f} 09 \% 2$ fjustice-on-tracks-and-the$\% 25 \mathrm{e} 2 \% 2580 \% 259 \mathrm{c} 1 \mathrm{st}$-international-meeting-of-the-people-affected-byvale $\% 25 \mathrm{e} 2 \% 2580 \% 259 \mathrm{~d} \% 2 \mathrm{f}>$. Acesso em $21 \mathrm{dez} .2017$.

WANDERLEY, Luiz Jardim de Moraes. Conflitos e impactos ambientais na exploração dos recursos minerais na Amazônia. Rio de Janeiro, GEOPUC, v. 3, p. 1-26, 2009.

Artigo recebido em: 02/05/2018.

Artigo aceito em: 25/07/2018.

\section{Como citar este artigo (ABNT):}

NETO, A. J. M.; REBELO, R. E. S. MOVIMENTOS SOCIAIS FRENTE ÀS GRANDES MINERADORAS NO BRASIL. Veredas do Direito, Belo Horizonte, v. 15, n. 32, p. 249-275, mai./ago. 2018. Disponível em: <http:// www.domhelder.edu.br/revista/index.php/veredas/article/view/1240>. Acesso em: dia mês. ano. 